\title{
Does lobectomy for lung cancer in patients with chronic obstructive pulmonary disease affect lung function? A multicenter national study
}

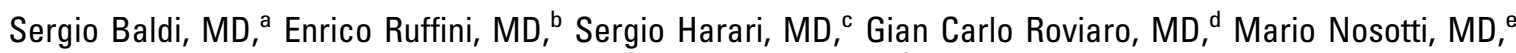
Nadia Bellaviti, MD, ${ }^{\mathrm{e}}$ Federico Venuta, MD, ${ }^{\mathrm{f}}$ Daniele Diso, MD, ${ }^{\mathrm{f}}$ Federico Rea, MD, ${ }^{\mathrm{g}}$ Claudio Schiraldi, MD, ${ }^{\mathrm{h}}$ Alberto Durigato, MD, ${ }^{i}$ Maurizio Pavanello, MD, ${ }^{\mathrm{j}}$ Angelo Carretta, MD, ${ }^{\mathrm{k}}$ and Piero Zannini, MD ${ }^{\mathrm{k}}$

Objective: The purpose of this study was to evaluate the effect of lobectomy on pulmonary function in patients with chronic obstructive pulmonary disease.

Methods: One hundred thirty-seven patients were analyzed; 49 had normal pulmonary function tests, and 88 had chronic obstructive pulmonary disease. Different functional parameter groups were identified: obstructive (forced expiratory volume in 1 second $\left[\mathrm{FEV}_{1}\right]$, forced expiratory volume in 1 second/forced vital capacity $\left[\mathrm{FEV}_{1} / \mathrm{FVC}\right]$, and chronic obstructive pulmonary disease index), hyperinflation (residual volume and functional residual capacity), and diffusion (transfer factor of the lung for carbon monoxide). Also, the ratio between observed and predicted postoperative $\mathrm{FEV}_{1}$ was calculated.

Results: In patients with preoperative $\mathrm{FEV}_{1}$ greater than $80 \%$ of predicted, postoperative $\mathrm{FEV}_{1} / \mathrm{FVC}$ slightly but not significantly decreased, and postoperative $\mathrm{FEV}_{1}$ significantly decreased. In patients with preoperative $\mathrm{FEV}_{1}$ less than $65 \%$, postoperative $\mathrm{FEV}_{1}$ and $\mathrm{FEV}_{1} / \mathrm{FVC}$ significantly increased. In patients with preoperative $\mathrm{FEV}_{1} / \mathrm{FVC}$ greater than $70 \%$, postoperative $\mathrm{FEV}_{1}$ and $\mathrm{FEV}_{1} / \mathrm{FVC}$ significantly

From the Pulmonary Division ${ }^{\mathrm{a}}$ and Division of Thoracic Surgery, ${ }^{\mathrm{b}}$ University Hospital S. Giovanni Battista of Torino, Torino, Italy, Pulmonary Division ${ }^{c}$ and Department of Surgery, Division of General Surgery, ${ }^{\mathrm{d}}$ University Hospital S. Giuseppe, Milano, Italy, Division of Thoracic Surgery, Policlinico IRCCS, University of Milano, Milano, Italy, ${ }^{\mathrm{e}}$ Department of Thoracic Surgery, Division of Thoracic Surgery, Policlinico Umberto I, University of Roma La Sapienza, Rome, Italy, ${ }^{\mathrm{f}}$ Department of Thoracic Surgery, Division of Thoracic Surgery, ${ }^{\mathrm{g}}$ and Pulmonary Division, ${ }^{\mathrm{h}}$ University Hospital of Padova, Padova, Italy, Pulmonary Division ${ }^{\mathrm{i}}$ and Division of Thoracic Surgery, ${ }^{\mathrm{j}}$ Ospedale Ca' Foncello, Treviso, Italy, and Division of Thoracic Surgery, Ospedale S. Raffaele IRCCS, Milan, Italy. ${ }^{k}$

Received for publication Feb 16, 2005; revisions received April 15, 2005; accepted for publication June 7, 2005.

Address for reprints: Sergio Baldi, MD, Respiratory Diseases, Ospedale S. Giovanni Battista, 3 Via Genova, Torino 10126, Italy (E-mail: baldi_sergio@hotmail.com).

J Thorac Cardiovasc Surg 2005;130:1616-22 $0022-5223 / \$ 30.00$

Copyright (C) 2005 by The American Association for Thoracic Surgery

doi:10.1016/j.jtcvs.2005.06.049 decreased. In patients with preoperative $\mathrm{FEV}_{1} / \mathrm{FVC}$ less than $70 \%$, postoperative $\mathrm{FEV}_{1} / \mathrm{FVC}$ increased, and $\mathrm{FEV}_{1}$ remained unchanged. In patients with a chronic obstructive pulmonary disease index greater than 1.5 , postoperative $\mathrm{FEV}_{1}$ and $\mathrm{FEV}_{1} / \mathrm{FVC}$ significantly decreased, whereas in patients with a chronic obstructive pulmonary disease index less than 1.5 , postoperative $\mathrm{FEV}_{1} / \mathrm{FVC}$ significantly increased and $\mathrm{FEV}_{1}$ remained unchanged. In patients with residual volume and functional residual capacity greater than $115 \%$ and transfer factor of the lung for carbon monoxide less than $80 \%$ of predicted, postoperative $\mathrm{FEV}_{1}$ diminished less (not significant) compared with patients who had residual volume and functional residual capacity less than $115 \%(P=.0001)$. Observed postoperative/predicted postoperative $\mathrm{FEV}_{1}$ was higher if $\mathrm{FEV}_{1} / \mathrm{FVC}$ was less than $55 \%$ (1.46), if $\mathrm{FEV}_{1}$ was less than $80 \%$ of predicted (1.21), or if the chronic obstructive pulmonary disease index was less than 1.5 (1.17).

Conclusions: Patients with mild to severe chronic obstructive pulmonary disease could have a better late preservation of pulmonary function after lobectomy than healthy patients.

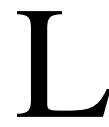
ung cancer remains an important cause of death among smokers, and this condition is often associated with chronic obstructive pulmonary disease (COPD). Surgical resection offers the best chance for curing lung cancer, and lobectomy is the most frequent operation performed. Postoperative respiratory failure is a widely known complication that limits parenchymal resection in patients with COPD; exclusion criteria have been adopted to evaluate these patients, and 


\section{Abbreviations and Acronyms \\ COPD = chronic obstructive pulmonary disease \\ $\mathrm{FEV}_{1}=$ forced expiratory volume in 1 second \\ $\mathrm{FEV}_{1}(\%)=\mathrm{FEV}_{1}$ percentage of predicted \\ FRC = functional residual capacity \\ FVC = forced vital capacity \\ PFT = pulmonary function test \\ $\mathrm{RV} \quad=$ residual volume \\ TLCO = transfer factor of the lung for carbon monoxide}

most of them outline the importance of preoperative forced expiratory volume in 1 second $\left(\mathrm{FEV}_{1}\right), \mathrm{FEV}_{1}$ /forced vital capacity (FVC), and transfer factor of the lung for carbon monoxide (TLCO). The 6-minute walking test, Master test, maximum oxygen consumption per unit time test, and prediction of postoperative $\mathrm{FEV}_{1}$ by different formulas are also used to evaluate postoperative risk. ${ }^{1}$ More recently, lung volume reduction surgery and recent reports on COPD patients operated on for lung cancer have revised the lung function evaluation and predictors for COPD patients who are candidates for lung resection. ${ }^{2-7}$ Unfortunately, most of these reports on lobectomy in patients with airway obstruction reviewed a limited number of cases, and the selection of operable patients remains a great challenge. ${ }^{2-7}$ The goal of this study was to evaluate the effect of lobectomy on pulmonary function in COPD patients.

\section{Materials and Methods}

This was a retrospective, multicenter national study. Data from 7 Italian hospitals with thoracic surgery experience (including lung transplantation, lung volume reduction surgery, or both) were collected. All patients with at least 1 preoperative and 1 postoperative pulmonary function evaluation who underwent lobectomy for lung cancer from March 1997 to March 2003 were considered; usually no more than a 6-month period was analyzed for each center. Postoperative pulmonary function tests (PFTs) were performed not earlier than the third postoperative month and not later than the 15 th month. Patients who received any adjuvant or neoadjuvant therapy were not considered eligible for this study. One hundred thirty-seven patients met the criteria (35 women and 102 men); 49 had normal static and dynamic pulmonary function, according to European Respiratory Society 1993, whereas 88 had COPD ranging from grade 1 to 3 according to Global Initiative on Obstructive Lung Disease guidelines. Hyperinflation was considered if residual volume (RV) and functional residual capacity (FRC) were greater than $115 \%$ of predicted and vital capacity was in the normal limit, and impairment of gas transfer was defined as TLCo less than $80 \%$ of predicted. PFTs were performed in different laboratories by using the European Respiratory Society 1993 predicting values. All tests were performed with the same methods, and static volumes were measured by the nitrogen washout method. Patients were evaluated by radiograph and computed tomographic scan to stage the tumor, to ascertain the presence of
TABLE 1. Study population

\begin{tabular}{|c|c|c|c|}
\hline Variable & $\begin{array}{c}\text { COPD } \\
\text { (88 patients) }\end{array}$ & $\begin{array}{c}\text { Normal } \\
\text { (49 patients) }\end{array}$ & $P$ value \\
\hline FVC $\%$ & $96 \pm 17$ & $102 \pm 16$ & $P=.04$ \\
\hline $\mathrm{FEV}_{1}(\%)$ & $63 \pm 8$ & $98 \pm 15$ & $P=.00001$ \\
\hline $\mathrm{FEV}_{1} / \mathrm{FVC}$ & $58 \pm 8$ & $76 \pm 5$ & $P=.00001$ \\
\hline COPD index & $1.28 \pm 0.26$ & $1.71 \pm 0.23$ & $P=.00001$ \\
\hline $\mathrm{RV} \%$ & $117 \pm 26$ & $103 \pm 27$ & $P=.001$ \\
\hline TLC $\%$ & $100 \pm 13$ & $99 \pm 13$ & $P=.6$ \\
\hline TLCO $\%$ & $69 \pm 17$ & $85 \pm 22$ & $P=.00001$ \\
\hline $\mathrm{PaO}_{2}$-pre $(\mathrm{mm} \mathrm{Hg})$ & $80 \pm 9$ & $84 \pm 8$ & $P=.01$ \\
\hline $\mathrm{PaCO}_{2}$-post $(\mathrm{mm} \mathrm{Hg})$ & $36 \pm 5$ & $39 \pm 3$ & $P=.002$ \\
\hline
\end{tabular}

$C O P D$, Chronic obstructive pulmonary disease; $F V C$, forced vital capacity; $F E V_{1}(\%)$, forced expiratory volume in 1 second percentage of predicted; $R V$, residual volume; $T L C$, total lung capacity; $T L C O$, transfer factor of the lung for carbon monoxide.

a flattening diaphragm, and to distinguish bullous from nonbullous emphysema.

Ninety-two patients underwent upper lobectomy, 37 underwent lower lobectomy, and 8 underwent middle lobectomy; $17 \%$ of these patients had bullous emphysema, and $32 \%$ had diaphragmatic flattening. Thirty-one had squamous cell cancer, 72 had adenocarcinoma, 5 had small cell lung cancers, and 4 had carcinoid tumors. In 25 patients, histologic results were not available or were uncertain.

In all patients, the observed postoperative $\mathrm{FEV}_{1}$ was compared with the predicted postoperative $\mathrm{FEV}_{1}$ by the observed postoperative/ predicted postoperative $\mathrm{FEV}_{1}$ ratio. The predicted postoperative $\mathrm{FEV}_{1}$ value was calculated with the following equation:

$$
\begin{aligned}
\text { Predicted postperative } \mathrm{FEV}_{1}= & \text { Preoperative } \mathrm{FEV}_{1} \\
& \times \text { (No. of segments remaining/ } \\
& \text { Total no. of segments })
\end{aligned}
$$

The COPD index was calculated according to Korst and associates $^{5}$ to evaluate the severity and purity of obstructive airway disease; the preoperative $\mathrm{FEV}_{1}$ (percentage of predicted in decimal form; $\mathrm{FEV}_{1} \%$ ) was added to the preoperative ratio of $\mathrm{FEV}_{1}$ to FVC. Patients with the lowest COPD index are those with the most severe airway obstruction. Patients with a COPD index greater than 1.5 do not have obstructive diseases.

The mean age of COPD patients was $68 \pm 15$ years, and the mean age of non-COPD patients was $66 \pm 13$ years (mean \pm SD). $\mathrm{FEV}_{1}$ ranged from $980 \mathrm{~mL}$ (34\% of predicted) to $4050 \mathrm{~mL}(115 \%$ of predicted) in the entire study population. Preoperative functional data in healthy and COPD patients are shown in Table 1.

Statistical analysis included the paired $t$ test for comparison of preoperative and postoperative mean values, because the patients were observed before and after a single treatment. Smith's statistical software package version 2.5, 2001 (by G. Smith, Claremont, Calif) was used for all analyses. Statistical methods included multiple comparisons of interrelated parameters, and this may cause problems with determining the appropriate significance level. To overcome this problem, we computed the number of comparisons for each category group (each table) and decreased the significance level by an appro- 
TABLE 2. FEV 1 group data

\begin{tabular}{|c|c|c|c|c|}
\hline \multicolumn{5}{|c|}{ FEV $_{1}>65 \%$} \\
\hline Variable & FEV $_{1}<65 \%$ & $<80 \%$ & $\mathrm{FEV}_{\mathbf{1}} \geq 80 \%$ & FEV $_{1}<80 \%$ \\
\hline \multirow{3}{*}{$\begin{array}{l}\mathrm{FEV}_{1} \text {-pre }(\%) \\
\mathrm{FEV}_{1} \text {-post }(\%)\end{array}$} & $56 \pm 7$ & $69 \pm 3$ & $98 \pm 15$ & $63 \pm 8$ \\
\hline & $64 \pm 11$ & $65 \pm 17$ & $78 \pm 16$ & $65 \pm 14$ \\
\hline & $P=.0004$ & $P=.17$ & $P=.0001$ & $P=.29$ \\
\hline \multirow{3}{*}{$\begin{array}{l}\mathrm{FEV}_{1} / \mathrm{FVC} \text {-pre } \\
\mathrm{FEV}_{1} / \mathrm{FVC} \text { - } \\
\text { post }\end{array}$} & $55 \pm 10$ & $65 \pm 10$ & $70 \pm 8$ & $59 \pm 11$ \\
\hline & $64 \pm 11$ & $66 \pm 16$ & $66 \pm 10$ & $65 \pm 14$ \\
\hline & $P=.0004$ & $P=.7$ & $P=.06$ & $P=.004$ \\
\hline \multirow{2}{*}{$\begin{array}{l}\text { RV-pre }(\%) \\
\text { RV-post }(\%)\end{array}$} & $117 \pm 27$ & $114 \pm 22$ & $108 \pm 30$ & $116 \pm 24$ \\
\hline & $\begin{aligned} 94 & \pm 18 \\
P & =.0003\end{aligned}$ & $\begin{aligned} 91 & \pm 24 \\
P & =.0003\end{aligned}$ & $\begin{aligned} 84 & \pm 27 \\
P & =.0003\end{aligned}$ & $\begin{aligned} 93 & \pm 20 \\
P & =.00001\end{aligned}$ \\
\hline $\begin{array}{l}\mathrm{PaO}_{2}-\text { pre } \\
(\mathrm{mm} \mathrm{Hg})\end{array}$ & $83 \pm 9$ & $79 \pm 8$ & $84 \pm 8$ & $80 \pm 9$ \\
\hline \multirow{2}{*}{$\begin{array}{l}\mathrm{PaO}_{2}-\text { post } \\
(\mathrm{mm} \mathrm{Hg})\end{array}$} & $79 \pm 9$ & $78 \pm 8$ & $83 \pm 9$ & $79 \pm 9$ \\
\hline & $P=.7$ & $P=.6$ & $P=.7$ & $P=.5$ \\
\hline
\end{tabular}

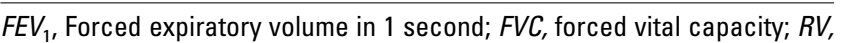
residual volume.

priate factor accordingly. In particular, for $4 \times 4$ comparisons, the significance level was decreased by 20 -fold (from .05 to .002), and for $4 \times 2$ comparisons, the significance level was decreased by 10 -fold (from .05 to .005).

\section{Results}

Flow volume and blood gas analyses were available in all patients, dynamic and static lung volumes were available in 108 patients, and carbon monoxide diffusion capacity was available in 89 patients. Preoperative chest radiographs and computed tomographic scans were examined in most COPD

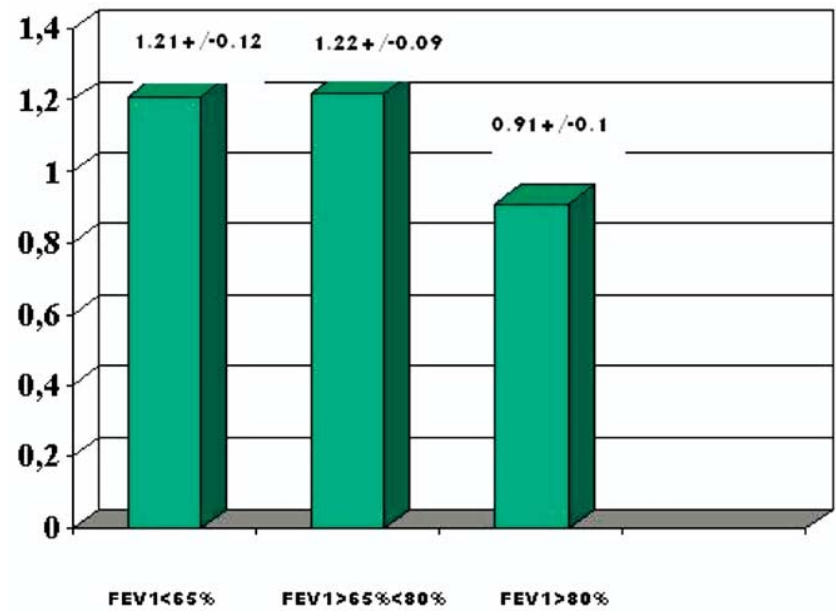

Figure 1. Observed postoperative/predicted postoperative FEV ratio according to $\mathrm{FEV}_{\mathbf{1}}(\%)$.
TABLE 3. FEV / FVC group data

\begin{tabular}{|c|c|c|c|c|}
\hline Variable & $\begin{array}{c}\text { FEV }_{1} / \text { FVC } \\
<55 \%\end{array}$ & $\begin{array}{c}\mathrm{FEV}_{1} / \mathrm{FVC} \\
>55<70 \%\end{array}$ & $\begin{array}{c}\text { FEV }_{\mathbf{1}} / \text { FVC } \\
\geq 70 \%\end{array}$ & $\begin{array}{c}\text { FEV }_{1} / \text { FVC } \\
<70 \%\end{array}$ \\
\hline $\begin{array}{l}\mathrm{FEV}_{1} \text {-pre }(\%) \\
\mathrm{FEV}_{1} \text {-post }(\%)\end{array}$ & $\begin{array}{c}60 \pm 13 \\
65 \pm 12 \\
P=.1\end{array}$ & $\begin{array}{c}76 \pm 14 \\
69 \pm 17 \\
P=.01\end{array}$ & $\begin{aligned} 96 & \pm 21 \\
78 & \pm 16 \\
P & =.00007\end{aligned}$ & $\begin{array}{c}70 \pm 67 \\
67 \pm 16 \\
P=.6\end{array}$ \\
\hline $\begin{array}{l}\mathrm{FEV}_{1} / \mathrm{FVC} \text {-pre } \\
\text { FEV }_{1} / \text { FVC-post }\end{array}$ & $\begin{aligned} 48 & \pm 15 \\
67 & \pm 16 \\
P & =.00002\end{aligned}$ & $\begin{array}{c}63 \pm 4 \\
64 \pm 14 \\
P=.6\end{array}$ & $\begin{aligned} 76 & \pm 5 \\
66 & \pm 10 \\
P & =.00001\end{aligned}$ & $\begin{array}{l}58 \pm 8 \\
65 \pm 13 \\
P=.0003\end{array}$ \\
\hline $\begin{array}{l}\text { RV-pre }(\%) \\
\text { RV-post }(\%)\end{array}$ & $\begin{aligned} 123 & \pm 25 \\
95 & \pm 18 \\
P & =.00009\end{aligned}$ & $\begin{aligned} 114 & \pm 26 \\
90 & \pm 23 \\
P & =.000001\end{aligned}$ & $\begin{aligned} 103 & \pm 27 \\
84 & \pm 27 \\
P & =.0007\end{aligned}$ & $\begin{aligned} 117 & \pm 26 \\
93 & \pm 20 \\
P & =.000001\end{aligned}$ \\
\hline $\begin{array}{l}\mathrm{PaO}_{2} \text {-pre } \\
(\mathrm{mm} \mathrm{Hg})\end{array}$ & $83 \pm 9$ & $79 \pm 8$ & $84 \pm 8$ & $80 \pm 9$ \\
\hline $\begin{array}{l}\mathrm{PaO}_{2} \text {-post } \\
(\mathrm{mm} \mathrm{Hg})\end{array}$ & $\begin{array}{l}79 \pm 9 \\
P=.09\end{array}$ & $\begin{array}{r}78 \pm 8 \\
P=.5\end{array}$ & $\begin{array}{r}83 \pm 9 \\
P=.5\end{array}$ & $\begin{array}{r}79 \pm 9 \\
P=.4\end{array}$ \\
\hline
\end{tabular}

$F E V_{1}$, Forced expiratory volume in 1 second; $F V C$, forced vital capacity; $R V$, residual volume.

patients to consider diaphragmatic flattening and bullous emphysema. No postoperative differences were observed with regard to the lobectomy area because upper, lower, or middle lobe resection did not influence the postoperative $\mathrm{FEV}_{1}$ or $\mathrm{FEV}_{1} / \mathrm{FVC}$ change.

Patients were divided into different groups to characterize the grade of airway obstruction, the grade of hyperinflation, and the grade of carbon monoxide diffusion capacity. Changes of functional variables before and after operation were then analyzed.

\section{Obstructive Parameters $\left(\mathrm{FEV}_{1}[\%], \mathrm{FEV}_{1} / \mathrm{FVC}\right.$, and COPD Index)}

We analyzed patients by considering 3 airway obstruction parameters: $\mathrm{FEV}_{1}(\%), \mathrm{FEV}_{1} / \mathrm{FVC}$, and COPD index. For $\mathrm{FEV}_{1}(\%), \mathrm{FEV}_{1}$ group 1 included 65 patients with an $\mathrm{FEV}_{1}$ of $80 \%$ or more; $\mathrm{FEV}_{1}$ group 2 included 72 patients with $\mathrm{FEV}_{1}$ less than $80 \%$; $\mathrm{FEV}_{1}$ subgroup 2a included 37 patients with $\mathrm{FEV}_{1}$ less than 65\%; and FEV subgroup $2 \mathrm{~b}$ included 35 patients with $\mathrm{FEV}_{1}$ between $65 \%$ and $79 \%$. Among patients in $\mathrm{FEV}_{1}$ group 1, the postoperative $\mathrm{FEV}_{1}$ / FVC slightly but not significantly decreased, whereas $\mathrm{FEV}_{1}$ significantly decreased and $\mathrm{PaO}_{2}$ remained unchanged. In $\mathrm{FEV}_{1}$ group 2, $\mathrm{FEV}_{1} / \mathrm{FVC}$ significantly increased, and $\mathrm{FEV}_{1}$ and $\mathrm{PaO}_{2}$ remained mostly unchanged. In $\mathrm{FEV}_{1}$ subgroup $2 \mathrm{a}, \mathrm{FEV}_{1} / \mathrm{FVC}$ and $\mathrm{FEV}_{1}$ significantly increased, whereas in $\mathrm{FEV}_{1}$ subgroup 2b, both $\mathrm{FEV}_{1} / \mathrm{FVC}$ and $\mathrm{FEV}_{1}$ remained unchanged. RV significantly decreased on postoperative follow-up in all groups examined (Table 2). The observed postoperative/predicted postoperative ratio for $\mathrm{FEV}_{1}$ in $\mathrm{FEV}_{1}$ group 1 was lower $(0.91 \pm \mathrm{SD} 0.1)$ than in 


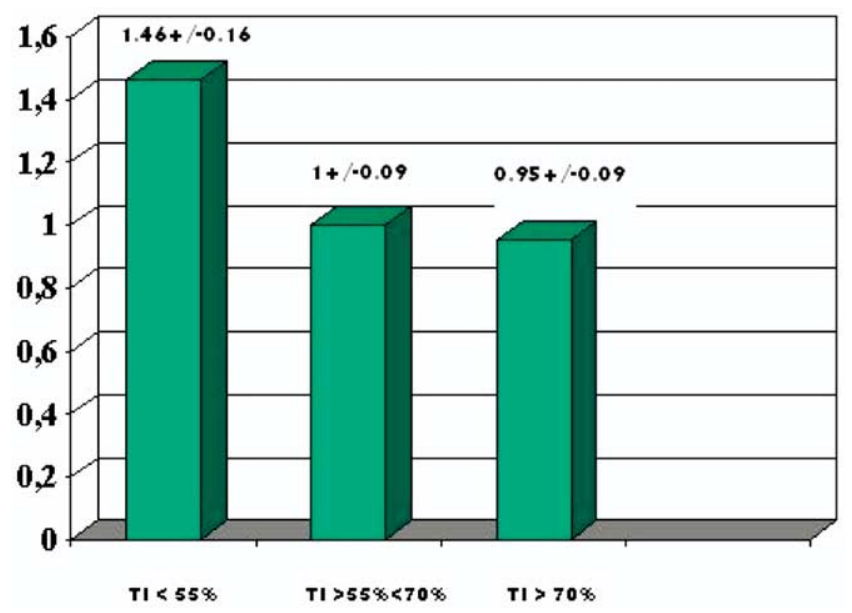

Figure 2. Observed postoperative/predicted postoperative FEV 1 ratio according to $\mathrm{TI}$. $T$, $\mathrm{FEV}_{\mathbf{1}} / \mathrm{FVC}$.

$\mathrm{FEV}_{1}$ group $2 \mathrm{a}(1.21 \pm \mathrm{SD} 0.12)$ and $\mathrm{FEV}_{1}$ group $2 \mathrm{~b}(1.22 \pm$ SD 0.09; Figure 1).

For $\mathrm{FEV}_{1} / \mathrm{FVC}, \mathrm{FEV}_{1} / \mathrm{FVC}$ group 1 included 49 patients with $\mathrm{FEV}_{1} / \mathrm{FVC}$ greater than $70 \% ; \mathrm{FEV}_{1} / \mathrm{FVC}$ group 2 included 88 patients with $\mathrm{FEV}_{1} / \mathrm{FVC}$ less than $70 \%$; $\mathrm{FEV}_{1} /$ $\mathrm{FVC}$ subgroup 2a included 29 patients with $\mathrm{FEV}_{1} / \mathrm{FVC}$ less than 55\%; and $\mathrm{FEV}_{1} / \mathrm{FVC}$ subgroup $2 \mathrm{~b}$ included 59 patients with $\mathrm{FEV}_{1} / \mathrm{FVC}$ between $55 \%$ and $69 \%$. In $\mathrm{FEV}_{1} / \mathrm{FVC}$ group $1, \mathrm{FEV}_{1}$ and $\mathrm{FEV}_{1} / \mathrm{FVC}$ significantly decreased, whereas $\mathrm{PaO}_{2}$ remained unchanged; in $\mathrm{FEV}_{1} / \mathrm{FVC}$ group 2, $\mathrm{FEV}_{1}$ and $\mathrm{PaO}_{2}$ remained mostly unchanged, whereas $\mathrm{FEV}_{1} /$ FVC significantly increased. It is interesting to note that in $\mathrm{FEV}_{1} / \mathrm{FVC}$ subgroup $2 \mathrm{a}, \mathrm{FEV}_{1}$ slightly increased (not sig-

TABLE 4. COPD index group data

\begin{tabular}{|c|c|c|}
\hline Variable & COPD index $<1.5$ & COPD index $>1.5$ \\
\hline $\begin{array}{l}\mathrm{FEV}_{1} \text {-pre }(\%) \\
\mathrm{FEV}_{1} \text {-post }(\%)\end{array}$ & $\begin{array}{c}65 \pm 10 \\
66 \pm 15 \\
P=.6\end{array}$ & $\begin{array}{l}99 \pm 17 \\
77 \pm 16 \\
P=.000001\end{array}$ \\
\hline $\begin{array}{l}\mathrm{FEV}_{1} / \mathrm{FVC} \text {-pre } \\
\mathrm{FEV}_{1} / \mathrm{FVC} \text {-post }\end{array}$ & $\begin{aligned} 58 & \pm 10 \\
65 & \pm 13 \\
P & =.0001\end{aligned}$ & $\begin{aligned} 72 & \pm 8 \\
65.9 & \pm 10 \\
P & =.001\end{aligned}$ \\
\hline $\begin{array}{l}\text { RV-pre }(\%) \\
\text { RV-post }(\%)\end{array}$ & $\begin{aligned} 116 & \pm 23 \\
93 & \pm 20 \\
P & =.000001\end{aligned}$ & $\begin{aligned} 109 & \pm 37 \\
84 & \pm 27 \\
P & =.0002\end{aligned}$ \\
\hline $\begin{array}{l}\mathrm{PaO}_{2} \text {-pre }(\mathrm{mm} \mathrm{Hg}) \\
\mathrm{PaO}_{2} \text {-post }(\mathrm{mm} \mathrm{Hg})\end{array}$ & $\begin{array}{r}79.9 \pm 9 \\
79.5 \pm 9 \\
P=.7\end{array}$ & $\begin{array}{r}85 \pm 8 \\
83 \pm 9 \\
P=.2\end{array}$ \\
\hline
\end{tabular}

COPD, Chronic obstructive pulmonary disease; $F E V_{1}$, forced expiratory volume in 1 second; $F V C$, forced vital capacity; $R V$, residual volume.

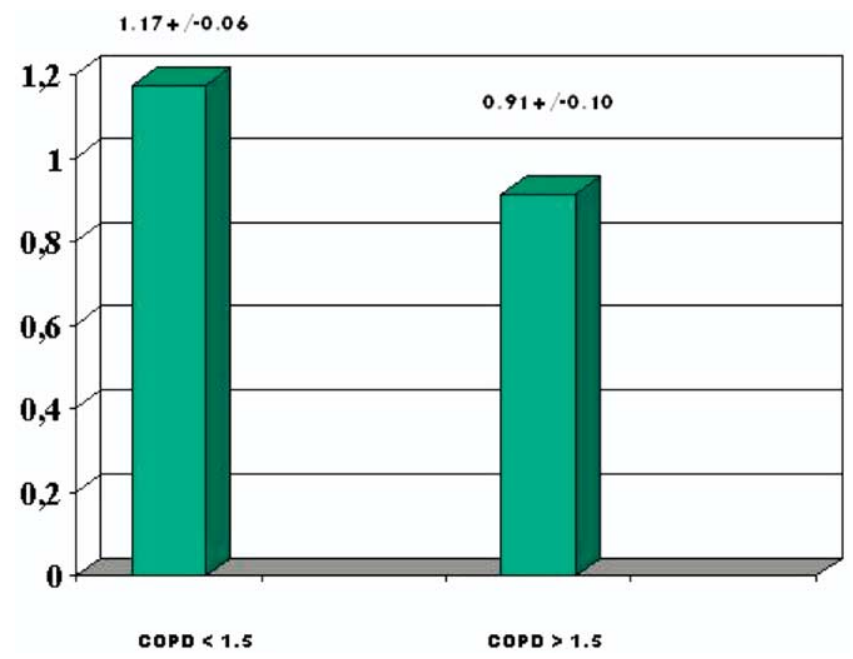

Figure 3. Observed postoperative/predicted postoperative FEV ratio according to COPD index.

nificant) and $\mathrm{FEV}_{1} / \mathrm{FVC}$ significantly increased, but in $\mathrm{FEV}_{1} / \mathrm{FVC}$ subgroup $2 \mathrm{~b}, \mathrm{FEV}_{1}$ decreased and $\mathrm{FEV}_{1} / \mathrm{FVC}$ remained unchanged (Table 3). The observed postoperative/ predicted postoperative ratio for $\mathrm{FEV}_{1}$ in $\mathrm{FEV}_{1} / \mathrm{FVC}$ subgroup $2 \mathrm{a}$ was significantly higher $(1.46 \pm \mathrm{SD} 0.16)$ than in $\mathrm{FEV}_{1} / \mathrm{FVC}$ subgroup $2 \mathrm{~b}\left(1 \pm \mathrm{SD}\right.$ 0.09) and $\mathrm{FEV}_{1} / \mathrm{FVC}$ group 1 (0.95 \pm SD 0.09; Figure 2).

COPD index group 1 included 52 patients with an index greater than 1.5, and COPD index group 2 included 85 patients with an index less than 1.5. In COPD group $1, \mathrm{FEV}_{1} / \mathrm{FVC}$ and

\section{TABLE 5. RV group data}

\begin{tabular}{|c|c|c|}
\hline Variable & RV $<115 \%$ & $\mathrm{RV}>115 \%$ \\
\hline $\begin{array}{l}\mathrm{FEV}_{1} \text {-pre }(\%) \\
\mathrm{FEV}_{1} \text {-post }(\%)\end{array}$ & $\begin{array}{l}89 \pm 21 \\
79 \pm 17 \\
P=.007\end{array}$ & $\begin{array}{r}73.8 \pm 19 \\
67 \pm 14 \\
P=.06\end{array}$ \\
\hline $\begin{array}{l}\mathrm{FEV}_{1} / \text { FVC-pre } \\
\text { FEV }_{1} / \text { FVC-post }\end{array}$ & $\begin{array}{r}69 \pm 12 \\
68.9 \pm 10 \\
P=.1\end{array}$ & $\begin{aligned} 59 & \pm 10 \\
60 & \pm 11 \\
P & =.06\end{aligned}$ \\
\hline $\begin{array}{l}\text { RV-pre }(\%) \\
\text { RV-post }(\%)\end{array}$ & $\begin{aligned} 91 & \pm 16 \\
78 & \pm 22 \\
P & =.0006\end{aligned}$ & $\begin{aligned} 133 & \pm 22 \\
104 & \pm 18 \\
P & =.00001\end{aligned}$ \\
\hline $\begin{array}{l}\text { Observed postop/predicted } \\
\text { postop } \mathrm{FEV}_{1}\end{array}$ & $1.02 \pm 0.084$ & $1.08 \pm 0.091$ \\
\hline $\begin{array}{l}\mathrm{PaO}_{2} \text {-pre }(\mathrm{mm} \mathrm{Hg}) \\
\mathrm{PaO}_{2} \text {-post }(\mathrm{mm} \mathrm{Hg})\end{array}$ & $\begin{array}{l}84 \pm 9 \\
80 \pm 8 \\
P=.06\end{array}$ & $\begin{array}{c}81 \pm 10 \\
81 \pm 9 \\
P=.1\end{array}$ \\
\hline
\end{tabular}

$R V$, Residual volume; $F E V_{1}$, forced expiratory volume in 1 second; $F V C$, forced vital capacity. 
TABLE 6. FRC group data

\begin{tabular}{lcc}
\hline \multicolumn{1}{c}{ Variable } & FRC $<\mathbf{1 1 5 \%}$ & FRC $>\mathbf{1 1 5 \%}$ \\
\hline FEV $_{1}$-pre (\%) & $87 \pm 20$ & $79 \pm 24$ \\
FEV $_{1}$-post (\%) & $74 \pm 17$ & $72 \pm 16$ \\
& $P=.0005$ & $P=.07$ \\
\hline FEV $_{1}$ /FVC-pre & $70 \pm 12$ & $60 \pm 11$ \\
FEV $_{1}$ /FVC-post & $68 \pm 11$ & $61 \pm 11$ \\
& $P=.3$ & $P=.6$ \\
\hline RV-pre (\%) & $88.9 \pm 14$ & $119 \pm 4$ \\
RV-post (\%) & $76 \pm 22$ & $103 \pm 14$ \\
& $P=.0004$ & $P=.00001$ \\
\hline Observed postop/predicted & $1.03 \pm 0.089$ & $1.04 \pm 0.082$ \\
postop FEV $_{1}$ & & \\
\hline Pao $_{2}$-pre (mm Hg) & $83 \pm 9$ & $81 \pm 9$ \\
Pao $_{2}$-post (mm Hg) & $80 \pm 10$ & $82 \pm 10$ \\
& $P=.1$ & $P=.5$ \\
\hline
\end{tabular}

FRC, Functional residual capacity; $F E V_{1}$, forced expiratory volume in 1 second; $F V C$, forced vital capacity; $R V$, residual volume.

$\mathrm{FEV}_{1}$ significantly decreased, whereas in COPD group 2, $\mathrm{FEV}_{1} / \mathrm{FVC}$ significantly increased, and $\mathrm{FEV}_{1}$ remained unchanged (Table 4). The observed postoperative/predicted postoperative ratio for $\mathrm{FEV}_{1}$ in group $2(1.17 \pm \mathrm{SD} 0.06)$ was higher than in group $1(0.91 \pm \mathrm{SD} 0.1$; Figure 3$)$.

\section{Hyperinflation Parameters (RV and FRC)}

RV group 1 included 53 patients with RV greater than $115 \%$, and RV group 2 included 55 patients with RV less than $115 \%$. In RV group $1, \mathrm{FEV}_{1}$ slightly $(P=.06)$ decreased, and $\mathrm{FEV}_{1} / \mathrm{FVC}$ remained unchanged; in RV group 2, $\mathrm{FEV}_{1}$ significantly decreased, and $\mathrm{FEV}_{1} / \mathrm{FVC}$ remained unchanged (Table 5).

FRC group 1 included 55 patients with FRC greater than $115 \%$, and FRC group 2 included 53 patients with FRC less than $115 \%$. In FRC group $1, \mathrm{FEV}_{1}$ and $\mathrm{FEV}_{1} / \mathrm{FVC}$ remained statistically unchanged, whereas in FRC group 2, $\mathrm{FEV}_{1}$ decreased, and $\mathrm{FEV}_{1} / \mathrm{FVC}$ remained unchanged (Table 6).

\section{Alveolar Diffusion Parameter (TLCo)}

TLCO group 1 included 35 patients with a TLCO of $80 \%$ or more, and TLCO group 2 included 54 patients with a TLCO less than $80 \%$. In TLCO group $1, \mathrm{FEV}_{1}$ significantly decreased, whereas $\mathrm{FEV}_{1} / \mathrm{FVC}$ did not change; in TLCO group 2, $\mathrm{FEV}_{1}$ decreased, and $\mathrm{FEV}_{1} / \mathrm{FVC}$ increased, but these differences were not significant (Table 7).

\section{Discussion}

Our results suggest that pulmonary function after lobectomy improves - or at least diminishes less—in COPD patients as
TABLE 7. TLCo group data

\begin{tabular}{|c|c|c|}
\hline Variable & Dıco $<80 \%$ & Dıco $>\mathbf{8 0} \%$ \\
\hline $\begin{array}{l}\mathrm{FEV}_{1} \text {-pre }(\%) \\
\text { FEV }_{1} \text {-post }(\%)\end{array}$ & $\begin{array}{r}68 \pm 15 \\
63 \pm 14 \\
P=.07\end{array}$ & $\begin{array}{l}96 \pm 20 \\
83 \pm 15 \\
P=.003\end{array}$ \\
\hline $\begin{array}{l}\mathrm{FEV}_{1} / \mathrm{FVC} \text {-pre } \\
\mathrm{FEV}_{1} / \text { FVC-post }\end{array}$ & $\begin{array}{c}58 \pm 12 \\
60 \pm 13 \\
P=.4\end{array}$ & $\begin{array}{r}70 \pm 9 \\
69 \pm 8 \\
P=.6\end{array}$ \\
\hline $\begin{array}{l}\text { Observed postop/predicted } \\
\text { postop } \mathrm{FEV}_{1}\end{array}$ & $1.07 \pm 0.1$ & $1.02 \pm 0.08$ \\
\hline $\begin{array}{l}\mathrm{PaO}_{2} \text {-pre }(\mathrm{mm} \mathrm{Hg}) \\
\mathrm{PaO}_{2} \text {-post }(\mathrm{mm} \mathrm{Hg})\end{array}$ & $\begin{array}{r}78 \pm 8 \\
79 \pm 9 \\
P=.5\end{array}$ & $\begin{array}{r}84 \pm 8 \\
81 \pm 9 \\
P=.1\end{array}$ \\
\hline
\end{tabular}

TLCO, Transfer factor of the lung for carbon monoxide; DLCO, carbon monoxide diffusion in the lung; $F E V_{1}$, forced expiratory volume in 1 second; $F V C$, forced vital capacity.

compared with non-COPD patients and that this phenomenon is more evident in patients with more severe airway obstruction and hyperinflation. In particular, some of the preoperative functional parameters seem to be good predictors of late postoperative function improvement (or minimal change). $\mathrm{FEV}_{1} / \mathrm{FVC}$ improves if preoperative $\mathrm{FEV}_{1}$ is less than $65 \%$ of predicted, if preoperative $\mathrm{FEV}_{1} / \mathrm{FVC}$ is less than $55 \%$, or if the COPD index is less than 1.5 , whereas $\mathrm{FEV}_{1} / \mathrm{FVC}$ worsens if the preoperative $\mathrm{FEV}_{1} / \mathrm{FVC}$ is more than $70 \%$ and the COPD index is more than 1.5. FEV improves only if the preoperative $\mathrm{FEV}_{1}$ is less than $65 \%$; it always worsens when airway flow indexes, diffusion capacity, and RV or FRC are in the normal range. Neither obstruction parameters $\left(\mathrm{FEV}_{1}\right.$ and $\left.\mathrm{FEV}_{1} / \mathrm{FVC}\right)$ nor diffusion capacity provides information on postoperative RV changes, because this index always worsens after operation and seems unrelated to these indexes. No change was observed before and after operation regarding oxygen exchange, and these data are unrelated to the preoperative functional data. It is interesting to note that the observed postoperative $\mathrm{FEV}_{1}$ is better than the predicted postoperative $\mathrm{FEV}_{1}$ if $\mathrm{FEV}_{1} / \mathrm{FVC}$ is less than $70 \%$, if $\mathrm{FEV}_{1}$ is less than $80 \%$ of predicted, or if the COPD index is less than 1.5. TLCO and RV do not influence these variations. An important and practical consideration is that the predicted postoperative $\mathrm{FEV}_{1}$ underestimates the observed postoperative $\mathrm{FEV}_{1}$ by approximately $45 \%$ if the preoperative $\mathrm{FEV}_{1} / \mathrm{FVC}$ is less than $55 \%$ and by approximately $20 \%$ if the preoperative $\mathrm{FEV}_{1}$ is less than $80 \%$ of predicted.

Preoperative evaluation for lung resection in lung carcinoma has been well studied, and many reports have been published to evaluate the early and late operative risk for patients with obstructive airway diseases. ${ }^{8-11}$ Advances in an- 
esthesia and intensive care management can improve survival in some patients, but respiratory impairment in the long term remains a problem. Although many PFTs and exercise tests have been used to evaluate risk among these patients, obstructive indexes such as $\mathrm{FEV}_{1}$ and $\mathrm{FEV}_{1} / \mathrm{FVC}$ are still the most used criteria to exclude these patients from surgery. In general practice, a preoperative $\mathrm{FEV}_{1}$ less than $1.5 \mathrm{~L}$ or $60 \%$ of predicted or a predicted postoperative $\mathrm{FEV}_{1}$ less than $800 \mathrm{~mL}$ or $40 \%$ of predicted is considered a high risk for lobectomy. ${ }^{1}$ Lung volume reduction surgery has demonstrated that lung function and dyspnea can improve after removal of portions of the lung parenchyma in patients with emphysema. Pulmonary nodule resection and lung volume reduction are feasible and are associated with minimal morbidity and significant improvement in pulmonary function. ${ }^{12-17}$

These data suggest that limited parenchymal resection, as well as lobectomy, might be beneficial for preserving lung function in patients with COPD. Previous investigators have demonstrated the feasibility of limited resection in patients with respiratory impairment. ${ }^{18-21}$ Errett and colleagues ${ }^{21}$ noted little difference in postoperative outcome in individuals with moderate airflow obstruction (mean $\mathrm{FEV}_{1}$ of $1.56 \mathrm{~L}$ ); Miller and Hatcher ${ }^{19}$ noted little perioperative difficulty in individuals with severe airflow obstruction $\left(\mathrm{FEV}_{1}\right.$ less than $1.0 \mathrm{~L}$ ) who underwent limited resection. More recently, it has been reported that pulmonary function might remain unchanged or even improve after lobectomy in COPD patients. $^{2-5}$ Korst and colleagues ${ }^{5}$ reported that the mean change in $\mathrm{FEV}_{1}$ after lobectomy was $+3.7 \%$ among patients with a preoperative $\mathrm{FEV}_{1}$ of less than or equal to $60 \%$ of predicted and was $-15.7 \%$ for patients with a mean preoperative $\mathrm{FEV}_{1}$ of $69 \%$ of predicted. Sekine and associates ${ }^{2}$ documented that the postoperative ventilatory function in COPD patients who had lower or middle/lower lobectomies was better preserved than predicted.

The most important consideration from our study, as well as from other similar studies, ${ }^{2-5}$ is that some patients will have improved obstructive indexes after lobectomy: the increase of $\mathrm{FEV}_{1} / \mathrm{FVC}$ means that airway caliber or elastic recoil improves after resection. Our patients were identified retrospectively; therefore, we cannot know the precise nature of COPD and of the lung tissue resected (apart from the presence of bullae in a small group), but the consistent number of our sample implies that these results are not attributable to lung volume reduction surgery. Nevertheless, we can speculate that the mechanism of this airway improvement could be the relief of hyperinflation and/or chest wall mechanics, although this improvement should not be related to emphysematous lungs. Resection of a dead space in case of local pulmonary artery involvement could be another way to explain functional amelioration in some cases.
This study has several limitations. We analyzed only patients who had been discharged from the hospital, so we did not consider early postoperative mortality or early functional impairment. Furthermore, this was a retrospective study limited to the involvement of 7 different hospitals and selection of patients from different periods. Patients with available postoperative PFTs over a limited period (from the 3rd to 15 th postoperative months) and in a consecutive temporal selection were involved. Patients first referred to the respiratory specialist always performed postoperative PFTs, but patients referred to a surgeon usually did not perform postoperative PFTs. Therefore, the selection criteria are related to the specialist who first visited the patient, and this was usually related to the practitioner who addressed the patient for further evaluation of a pulmonary lesion.

In conclusion, patients with mild to severe COPD could present a better late preservation of pulmonary function after lobectomy compared with healthy patients. This minimal deterioration or improvement of airway function seems to be related to preoperative obstructive indexes.

\section{References}

1. Beckles MA, Spiro SG, Colice GL, et al. Initial evaluation of the patient with lung cancer. Symptoms, signs, laboratory tests, and paraneoplastic syndromes. Chest. 2003;123:97s-104s.

2. Sekine Y, Iwata T, Chiyo M, et al. Minimal alteration of pulmonary function after lobectomy in lung cancer patients with chronic obstructive pulmonary disease. Ann Thorac Surg. 2003;76:356-62.

3. Carretta A, Zannini P, Puglisi A, et al. Improvement of pulmonary function after lobectomy for non small cell lung cancer in emphysematous patients. Eur J Cardiothorac Surg. 1999;15:602-7.

4. Santambrogio L, Nosotti M, Baisi A, et al. Pulmonary lobectomy for lung cancer: a prospective study to compare patients with forced expiratory volume in $1 \mathrm{~s}$ more or less than $80 \%$ of predicted. Eur J Cardiothorac Surg. 2001;20:684-7.

5. Korst RJ, Ginsberg RJ, Ailawadi M, et al. Lobectomy improves ventilatory function in selected patients with severe COPD. Ann Thorac Surg. 1998;66:898-902.

6. DeMeester SR, Patterson GA, Sundaresan RS, et al. Lobectomy combined with volume reduction for patients with lung cancer and advanced emphysema. J Thorac Cardiovasc Surg. 1998;115:681-8.

7. Edward JG, Duthie DJ, Waller DA. Lobar volume reduction surgery: a method of increasing the lung cancer resection rate in patients with emphysema. Thorax. 2001;56:791-5.

8. Markos J, Mullan BP, Hillman DR, et al. Preoperative assessment as a predictor of mortality and morbidity after lung resection. Am Rev Respir Dis. 1989;139:902-10.

9. Boysen PG, Block AJ, Moulder PV. Relationship between preoperative pulmonary function tests and complications after thoracotomy. Surg Gynecol Obstet. 1981;152:813-5.

10. Boushy SF, Billig DM, Noth LB, et al. Clinical course related to preoperative and postoperative pulmonary function in patients with bronchogenic carcinoma. Chest. 1971;59:383-91.

11. Kearney DJ, Lee TH, Reilly JJ, et al. Assessment of operative risk in patients undergoing lung resection: importance of predicted pulmonary function. Chest. 1994;105:753-9.

12. Ojo CT, Martinez F, Paine R, et al. Lung volume reduction surgery alters management of pulmonary nodules in patients with severe COPD. Chest. 1997;112:1494-500.

13. Gelb AF, Brenner M, McKenna RJ, et al. Lung function 12 months following emphysema resection. Chest. 1996;110:1407-15. 
14. Choong CK, Meyers BF, Battaferano RJ, et al. Lung cancer resection combined with lung volume reduction in patients with severe emphysema. J Thorac Cardiovasc Surg. 2004;127:1323-31.

15. Mentzer SJ, Swanson SJ. Treatment of patients with lung cancer and severe emphysema. Chest. 1999;116:477S-479S.

16. Hayashi K, Fukushima K, Sagara Y, et al. Surgical treatment for patients with lung cancer complicated by severe pulmonary emphysema. J Thorac Cardiovasc Surg. 1999;47:583-7.

17. Rozenshtein A, White CS, Austin JH, et al. Incidental lung carcinoma detected at CT in patients selected for lung volume reduction surgery to treat severe pulmonary emphysema. Radiology. 1998;207:487-90.
18. Bennett W, Smith R. Segmental resection for bronchogenic carcinoma: a surgical alternative for the compromised patient. Ann Thorac Surg. 1979;27:169-72.

19. Miller J, Hatcher C. Limited resection of bronchogenic carcinoma in the patient with marked impairment of pulmonary function. Ann Thorac Surg. 1987;44:34-43.

20. Hoffman T, Ransdell H. Comparison of lobectomy and wedge resection for carcinoma of the lung. J Thorac Cardiovasc Surg. 1980;79:11-7.

21. Errett L, Wilson J, Chiu R, et al. Wedge resection as an alternative procedure for peripheral bronchogenic carcinoma in poor-risk patients. J Thorac Cardiovasc Surg. 1985;90:656-61.

\section{Bound volumes available to subscribers}

Bound volumes of The Journal of Thoracic and Cardiovascular Surgery are available to subscribers (only) for the 2005 issues from the Publisher, at a cost of $\$ 134.00$ for domestic, $\$ 165.85$ for Canadian, and $\$ 155.00$ for international subscribers for Vol 129 (January-June) and Vol 130 (July-December). Shipping charges are included. Each bound volume contains a subject and author index.

The binding is durable buckram with the Journal name, volume number, and year stamped in gold on the spine. Payment must accompany all orders. Contact Elsevier Inc., Subscription Customer Service, 6277 Sea Harbor Dr, Orlando, FL 32887, USA; phone 800-654-2452 or 407-345-4000.

Subscriptions must be in force to qualify. Bound volumes are not available in place of a regular Journal subscription. 